\title{
FILOSOFI SOSIOLOGIS GLOBALISASI DAN PEMBENTUKAN IDENTITAS KEAGAMAAN: INTERPRETASI GERAKAN HTI
}

\author{
Oleh: \\ Aidil Aulya* \\ Dosen Fakultas Syari'ah UIN Imam Bonjol Padang \\ aidilaulya89@gmail.com
}

\begin{abstract}
Abstrak
Artikel ini membuktikan ambiguisitas dan ambivalensi identitas HTI dalam menyikapi globalisasi yang dibuktikan dengan beberapa variabel. Ideologi khilafah yang menjadi misi HTI membawa konsep diferensialisme kultural. Artikel ini menggunakan teori globalisasi Appadurai (1996), yang menjelaskan unsur-unsur globalisasi, yaitu, Pertama, ethnoscape (orang). Kedua, technoscape (teknologi). Ketiga, financescape (modal). Keempat, mediascape (gambar). Kelima, ideoscape (ideologi) yang merupakan idealitas yang bersifat politis yang berhubungan langsung dengan misi global yang diusungnya. Temuan dalam artikel ini yaitu: Pertama, anNabhani sebagai pendiri dan sekaligus ideolog Hizbut Tahrir menyerukan homogenisasi kultural dan politik dalam bentuk daulah Islam. Kedua, ideologi tertutup yang digunakan oleh HTI menyebabkan akan terjadinya perbenturan dengan ideologi lainnya. Ketiga, penguasaan terhadap media dan teknologi merupakan instrumen utama dalam penyebaran ideologi HTI. Keempat, terjadi ambiguisitas sikap dan identitas HTI ketika berhadapan dengan identitas kultural yang bersifat lokalitas.
\end{abstract}

Kata Kunci: Globalisasi; HTI; identitas

\section{A. PENDAHULUAN}

Globalisasi merupakan artikulasi persoalan sejarah manusia. Dalam perkembangan selanjutnya, globalisasi secara tidak langsung membawa rasio kapitalisme dengan segala konsekuensinya. Efek globalisasi tersebut berimbas kepada etika budaya. Kapitalisme pada akhirnya membawa kepada peminggiran budaya asli dan diganti dengan budaya baru. Menurut Subhan, Republik Indonesia lahir bercirikan nasionalisme dan semangat integrasi yang dilandasi oleh pluralitas budaya. Ketika memasuki abad ke-21, globalisme secara evolutif mengubah tatanan kehidupan sosial masyarakat 
sehingga menjadi jauh dari akar kebudayaannya. Muncul nilai-nilai baru yang menggusur karakter asli budaya nasional dan rasa kebhinekaan (Subhan, 2005). Ditambah lagi dengan adanya transisi sistem politik Orde Baru dan direformasi menjadi demokrasi. Demokrasi dengan klaim kebebasannya membawa masyarakat Indonesia pada ambiguisitas kebudayaan sehingga melahirkan kenisbian, partikularitas, dan disorientasi.

Globalisasi mengakibatkan kaburnya garis-garis kebudayaan. Efek globalisasi tidak saja dipengaruhi oleh modernisasi di Barat namun juga oleh budaya Timur Tengah. Misalnya saja, model pakaian "muslim" di Indonesia merupakan pengaruh dari Arab sentris. Berjubah, berjenggot, dan celana cingkrang merupakan bentuk keterbelengguan identitas fashion yang terjebak dengan arab minded. Penegasan identitas fashion juga merupakan salah satu bentuk dari counter kultural terhadap kondisi modernitas yang terjadi.

Menarik untuk dianalisis bagaimana globalisasi dalam konteks kebudayaan berpengaruh secara signifikan terhadap pola beragama dan interpretasi terhadap ajaran agama. Kritikan penting terhadap globalisasi yang dibahas dalam tulisan ini adalah pemahaman mengenai globalisasi yang sangat identik dengan westernisasi. Mindset yang terkonstruksi selama ini di masyarakat mengenai globalisasi adalah westernisasi. Selama pemahaman terhadap globalisasi hanya dipersempit pada westernisasi, maka globalisasi hanya akan memunculkan semangat perlawanan terhadap Barat. Pada akhirnya kontestasi wacana dua kutub orientalisme dan oksidentalisme akan selalu berhadapan tanpa ada jalan keluar. Hal ini tentu sangat tidak produktif dalam pengayaan pemahaman keagamaan. Produk kontestasi dua kutub tersebut akan melahirkan pertarungan identitas antar masyarakat global. Faktanya, globalisasi dalam konteks apapun tidak bisa dihindari karena tidak ada komunitas masyarakat dan komunitas agama yang akan mengisolasi diri dari tatanan dunia global.

Islam di Barat menurut Pasha disimbolkan sebagai agama yang anti dengan modernitas, terbelakang, dan tidak bisa lepas dari kekerasan dalam ajaran agamanya. Politik Islam menurut Pasha dipandang sebagai fenomena anti modern dan anti terhadap segala sesuatu yang datang dari Barat (Pasha, 2002). Fenomena ini dianggap sebagai keterbelakangan dan tidak mau membuka diri dengan masyarakat global (global society). Pandangan simplifikasi terhadap Islam seperti ini tidak bisa diterima dan mengandung unsur kebencian dan fobia yang berlebihan terhadap Islam. Namun pandangan ini juga tidak bisa disalahkan sepenuhnya jika wajah Islam yang ditampilkan selama ini tidak jauh dari kekerasan dan nirmodernitas. Identitas Islam yang dimunculkan sebagai lawan dari globalisasi ide dan konsep yang datang dari barat ditunjukkan dengan simbol keislaman yang semakin kuat juga. Akan tetapi, identitas yang dimunculkan juga merupakan pengaruh dari globalisasi sebagai 
proses arabisasi. Fenomena tersebut terlihat dari pola pemahaman dan keberagamaan yang ditampilkan oleh gerakan Hizbut Tahrir Indonesia (HTI) di Indonesia.

HTI merupakan penegasan politik Islam dengan konsep syariatisasi sistem politik. Dalam pandangan sederhana, HTI muncul dari proses globalisasi karena termasuk dalam salah satu bagian organisasi transnasional. Menurut Wahid, diantara gerakan transnasional yang beroperasi di Indonesia yaitu: pertama, Ikhwanul Muslimin yang pada awalnya berinfiltrasi ke lembaga dakwah kampus dan pada akhirnya menjadi Partai Keadilan (sekarang menjadi Partai Keadilan Sejahtera) Kedua, Hizbut Tahrir dengan gagasan Pan Islamisme yang menginginkan adanya khilafah di Indonesia. Ketiga, kelompok Wahabi yang melakukan agenda wahabisasi global (A. Wahid, 2009). Terdapat ambivalensi sikap HTI terhadap globalisasi, menolak globalisasi namun lahir dari proses globalisasi. Tulisan ini mengkaji tentang esensi globalisasi dan relevansinya terhadap pola keberagamaan kelompok Islam. Diakui atau tidak sebenarnya globalisasi merupakan kondisi yang tidak bisa dihindari dan membuat kabur batas geografis suatu negara. Negara-negara menjadi tanpa batas (borderless) (Ohmae, 1992) dan ada sebab serta akibat yang muncul dari pola interaksi tanpa sekat dan batasan geografis. Ditambah lagi dengan peranan media yang mempunyai pengaruh besar terhadap perkembangan suatu negara. Konsep kebebasan yang terkandung dalam globalisasi bisa juga diartikan sebagai kebebasan dalam mendapatkan informasi. Permasalahan lain yang muncul adalah terjadinya distorsi informasi jika media informasi dihegemoni oleh kekuatan negaranegara kuat seperti Amerika. Setting media dan informasi yang disampaikan ke publik bisa menjadi alat propaganda untuk menanamkan ajaran-ajaran dan ideologisasi sesuai dengan yang diarahkan oleh pemilik media.

\section{B. PEMBAHASAN}

\section{Teori}

Menurut Ritzer dan Dean, definisi sosiologis globalisasi lazimnya melihat globalisasi sebagai proses atau kondisi (Ritzer \& Dean, 2013). Ritzer mendefinisikan globalisasi sebagai sebuah proses atau serangkaian proses lintas wilayah yang menyebabkan meningkatnya kecairan dan tumbuhnya arus manusia, benda, tempat, dan informasi multi arah. Sedangkan Rosenberg menjelaskan bahwa globalisasi merupakan sebab kondisi atau hasil dari proses-proses kultural, politik, dan ekonomi (Rosenberg, 2000). Dalam pandangan ini bisa diartikan bahwa kondisi globalitas merupakan sebuah kesadaran global atau kebudayaan dunia. Terlepas dari dua perdebatan ini, globalisasi dalam fenomena beragama sudah menyebabkan adanya penguatan identitas beragama. Munculnya kelompok-kelompok yang corak keagamaannya lebih menekankan pada simbolitas dan identitas bisa dianggap sebagai perlawanan atau reaksi terhadap globalisasi. 
Diskursus

globalisasi tidak bisa dipisahkan dengan konteks demokrasi. Menurut Pasha, demokratisasi merupakan akibat dan konsekuensi dari globalisasi (Pasha, 2002). Penerimaan terhadap demokrasi merupakan pintu masuk globalisasi, karena demokrasi menekankan kebebasan dalam setiap aspeknya. Namun yang patut dicatat dan menjadi perhatian khusus adalah efek globalisasi yang bisa saja menghancurkan kohesi sosial dan solidaritas kelompok. Hal ini disebabkan oleh adanya kebebasan individu yang berlebihan dan mengakibatkan munculnya sikap individualistik. Efek globalisasi dalam konteks agama tidak jauh berbeda dengan efek globalisasi dalam bidang ekonomi. Globalisasi ekonomi sangat mempengaruhi aspek lain, termasuk cara beragama dan identitas beragama. Kondisi globalitas yang mendatangkan globalisasi menyebabkan terjadinya penguatan nilai-nilai lokalitas dan identitas.

Teori globalisasi muncul sebagai akibat dari serangkaian perkembangan internal teori sosial, khususnya reaksi terhadap perspektif seperti teori modernisasi. Diantara karakteristik dari teori ini adalah bias westernisasi disesuaikan dengan perkembangan di Barat dan bahwa ide di luar dunia Barat tak punya pilihan kecuali menyesuiakan ide dengan ide Barat. Terdapat beberapa pendekatan dalam menelaaah globalisasi. Para ahli sosiolog menggunakan beberapa teori untuk menggali esensi dari globalisasi. Pelbagai pendekatan ini tentu akan menghasilkan kesimpulan yang berbeda dalam memahami globalisasi.

Pada dasarnya globalisasi bukanlah konsep tunggal yang bisa dirumuskan dengan sederhana dan secara limitatif. Luasnya konsep mengenai globalisasi merupakan sebuah diskursus ilmu sosial yang akan selalu berdialektika untuk merumuskan globalisasi dalam segala aspek dan sudut pandang. Ideologi politik individu, geografis, status sosial, latar belakang budaya, serta afiliasi etnis dan agama akan memberikan perspektif tentang globalisasi dan menentukan bagaimana globalisasi bisa diinterpretasikan. Berdasarkan sifatnya globalisasi mencakup banyak disiplin ilmu, masyarakat, dan budaya. Hal ini tentu saja memungkinkan menelaah globalisasi dari pelbagai perspektif. Konsep globalisasi menurut Larsson adalah proses penyusutan dunia, jarak semakin pendek, hal-hal bergerak lebih dekat. Berkaitan dengan semakin mudahnya seseorang berinteraksi di satu sisi dunia, untuk saling menguntungkan dengan seseorang di sisi lainnya (Weller, 2005). Istilah ini digunakan untuk menggambarkan perubahan di dalam masyarakat dan perubahan ekonomi yang diakibatkan oleh adanya peningkatan komunikasi lintas budaya. Dampak dari adanya globalisasi sebagaimana yang disebutkan oleh McLuhan adalah keterhubungan antar budaya yang akan membentuk budaya massa global (global village) (McLuhan, 1962). Dalam konteks ekonomi, konsep globalisasi merupakan proses 
global yang berlangsung dalam bidang pasar keuangan, produksi dan investasi. Secara lebih spesifik dalam konteks ekonomi, globalisasi merupakan perdagangan bebas (free trade).

\section{Dalam}

http://www.newworldencyclopedia.or g/ dijelaskan bahwa term globalisasi muncul pada tahun 1962 dalam sebuah artikel di majalah Spectator. Kata globalisasi kemudian mulai dikenal setelah tahun 1962 dan dipublikasikan oleh McLuhan dalam buku The Guttenberg Galaxy. "Globalism" merupakan istilah yang lebih baru dan muncul pertama kalinya di tahun 1986 dalam edisi kedua The Oxford English Dictionary. Sedangkan menurut Kumar, istilah globalisasi pertama kali muncul pada tahun 1961 dalam Webster's Dictionary (Kumar, 2003). Hal ini menandakan bahwa globalisasi dalam konteks ilmu sosial merupakan hal baru yang lahir dari wacana postmodern. Globalisasi yang tercakup dalam diskursus postmodern mempunyai efek yang sama.

Banyaknya definisi mengenai globalisasi perlu didiskusikan agar bisa dirumuskan definisi yang lebih komprehensif dan relevan dengan permasalahan dalam tulisan ini. Menurut Kumar, perdebatan mengenai definisi globalisasi sangat banyak dan tidak akan habisnya tergantung dari perspektif mana istilah ini digunakan. Kumar merangkum beberapa pendekatan dalam mengartikan istilah globalisasi, yaitu dengan pendekatan sosiologi, ekonomi, hukum, ilmu politik dan hubungan internasional, serta teori sosial (Kumar, 2003). Al-Rodhan dan
Stoudman merangkum sebanyak 114 definisi mengenai globalisasi dari pelbagai perspektif atau interdisipliner keilmuan. Pada akhirnya disimpulkan bahwa globalisasi adalah penyebab dan konsekuensi dari integrasi transnasional dan transkultural yang disebabkan oleh aktivitas manusia dan selain manusia (Al-Rodhan \& Stoudmann, 2006). Definisi yang diberikan oleh Al-Rodhan dan Stoudman ini melihat globalisasi sebagai proses yang terus berlangsung. Giddens menjelaskan bahwa globalisasi bukan hanya soal ketergantungan ekonomi, namun tentang transformasi ruang dan waktu dalam kehidupan kita (Giddens, 1998). Berbeda dengan pendapat Nayef dan Stoudman, Giddens melihat globalisasi sebagai kondisi yang tidak bisa dihindari. Fokus diskursus dalam tulisan ini memakai definisi globalisasi yang digunakan oleh Nayef dan Stoudman.

Dari dua contoh definisi yang disebutkan, semakin terlihat bahwa term globalisasi menimbulkan perdebatan terminologis. Globalisasi menurut Wunderlich dan Warrier bisa saja dilihat sebagai proses, waktu, kekuatan, dan kondisi (Wunderlich \& Warrier, 2007). Fokus kajian ini yaitu melihat fenomena interelasi antara globalisasi dan agama. Jika agama adalah salah satu cara yang paling mendasar untuk mengorganisir kehidupan manusia, maka benih globalisasi sudah terletak di dalam agama itu sendiri. Di dalam agama terkandung nilai-nilai universal dan nilai tersebut bisa menjadi etika sosial yang mengikat masyarakat global. Diskursus menarik yang 
dipaparkan oleh Hopkins menjelaskan bahwa tidak mungkin melupakan agama dalam konteks diskursus mengenai globalisasi. Hal itu disebabkan karena adanya implikasi globalisasi terhadap agama atau sebaliknya (Hopkins, 2001). Bahkan dalam bahasa yang lebih ekstrim, tesis Hopkins menyatakan bahwa globalisasi itu sebagai sebuah agama (Hopkins, 2001).

Konsekuensi dari perkembangan sains dan teknologi modern, terutama dalam bidang komunikasi, adalah terjadinya globalisasi. Terjadinya globalisasi yang bergulir di dunia saat ini telah membawa konsekuensi bentrokan antar budaya. Modernisasi teknologi komunikasi membawa kemajuan seperti mesin giling yang menyangkal dan menghapus perbedaan budaya dengan cara tidak hanya menawarkan keuntungan (rasionalisasi, kontrol standardisasi) tetapi juga kerugian (keterasingan, perpindahan, kekecewaan). Berkembangnya budaya global di tengah identitas budaya lokal telah menjadi bentuk 'kekecewaan dunia' (Pieterse, 1996). Keterlibatan teknologi komunikasi telah menjadi unsur terpenting terjadinya globalisasi. Terjadinya proses ini telah banyak merubah cara pandang dan pola hidup masyarakat di berbagai bidang, baik itu bidang ekonomi, politik, hukum, maupun sosial budaya. Di dalam kaitan ini, menarik untuk diamati, bahwa media massa -terutama televisi dipandang sebagai media yang sangat spektakular dalam memfasilitasi terjadinya proses ini. Jaringan televisi di tuduh memegang peran besar dalam memfasilitasi penyebaran identitas global ke ranah lokal. Bermula dari kontinuitas tersebutlah, sehingga terjadi saling mempengaruhi dan ketergantungan antara media global dan lokal. Di dalam situasi begini, kesalahan dalam merespon globalisasi bisa berakibat fatal pada memudarnya identitas budaya lokal. Fenomena disiarkannya 'budaya global' di pelbagai media dan terjadinya perubahan cara pandang dan prilaku masyarakat merupakan bukti nyata telah terjadi pergeseran.

Pieterse mengidentifikasi tiga paradigma dalam teorisasi aspek kultural dari globalisasi. Tiga paradigma tersebut menjelaskan bahwa apakah globalisasi akan menyebabkan perbedaan kultural di seluruh dunia, mempersatukan kultur yang beragam, atau akan membentuk hibdrida kultural yang terbentuk dari kombinasi kultur global dan lokal (Pieterse, 2004). Teori Pieterse disebut sebagai teori kultural oleh Ritzer (Ritzer, 2014). Pertama, Diferensialisme kultural. Menurut Ritzer, para ahli yang menggunakan paradigma ini berpendapat bahwa di antara dan di kalangan kultur ada perbedaan lama yang sebagian besar tidak terpengaruh oleh globalisasi atau oleh proses transkultural, multikultural, dan bikultural lainnya (Ritzer, 2014). Ritzer menambahkan konsep diferensialisme kultural tersebut, yaitu: Pertama, globalisasi hanya terjadi di permukaan, sedangkan inti kulturalnya tetap tidak ada perubahan. Kedua, kultur inti yang tidak mengalami perubahan tersebut dianggap bersifat tertutup (Ritzer, 2014). Setidaknya bisa disimpulkan bahwa globalisasi tidak 
berpengaruh terhadap kultur inti atau bisa jadi ke identitas inti tidak hanya disebabkan oleh sifatnya yang tertutup sebagaimana pendapat Ritzer, namun bisa juga disebabkan oleh kuatnya kultur inti tersebut. Kuatnya kultur inti tersebut dari intervensi kultur lain bisa mengakibatkan efek yang paling ekstrim dengan terjadinya perbenturan peradaban sebagaimana tesis yang dibangun oleh Samuel P. Huntington. Benturan peradaban yang terjadi bisa saja terpola pada Barat vis a vis Timur (Islam dan Barat) atau mayoritas vis-a-vis minoritas. Kedua, konvergensi kultural. Paradigma konvergensi kultural menurut Ritzer didasarkan pada pengaruh globalisasi yang menyebabkan meningkatnya kesamaan di seluruh dunia (Ritzer, 2014). Artinya globalisasi membawa konsep homogenisasi kultural dan menyebabkan adanya perubahan kultur inti. Paradigma inilah yang menyebabkan adanya tendensi bahwa globalisasi merupakan westernisasi. Dengan menggunakan paradigma ini globalisasi bisa dianggap sebagai media untuk kelompok besar (mayoritas) bisa menancapkan hegemoninya kepada minoritas. Hal inilah yang terkadang disebut sebagai kapitalisme global, imperialisme global, dan lain-lain sebagai konsekuensi dasar yang tidak bisa dihindarkan akibat adanya globalisasi. Ketiga, hibridisasi kultural. Paradigma ini menekankan pada integrasi global dan lokal dan perpaduan keduanya memunculkan kultur hibrida. Paradigma ini memunculkan heterogenitas kultural dan identitas serta memunculkan kultur dan identitas baru.

\section{Metodologi}

Globalisasi dan relevansinya dalam pembentukan identitas keagamaan merupakan wilayah perdebatan kultural. Tentu ada aspek lain yang akan dipengaruhi oleh globalisasi selain aspek perubahan kultural. Seperti perkembangan interpretasi agama dengan pelbagai pendekatan keilmuan yang dibangun oleh sarjana-sarjana Barat. Tulisan ini hanya terfokus pada pembentukan identitas keagamaan dalam wilayah perdebatan kultural. Konsep pendekatan kultural ini digunakan sebagai alat analisis pembentukan corak identitas dan kultur keagamaan HTI.

Appadurai menjelaskan bahwa unsur-unsur globalisasi mencakup lima hal (Appadurai, 1996), yaitu: Pertama, ethnoscape (orang). Ini adalah aktor atau kelompok yang mobile (turis, pengungsi, pekerja tamu) yang memainkan peran penting dalam perubahan-perubahan di dunia tempat kita tinggal. Hal ini melibatkan gerakan aktual dan ideide tentang perubahan. Kedua, technoscape (teknologi). Hal ini merupakan konfigurasi global dari teknologi dan fakta bahwa teknologi sudah bergerak dengan kecepatan tinggi melintasi pelbagai batasan yang dulu ada. Artinya sudah tidak ada batasan geografis lagi seiring dengan perkembangan teknologi. Ketiga, financescape (modal). Hal ini melibatkan kekuatan modal sebagai mesin organik untuk menjalankan misi. Keempat, mediascape (gambar). Hal ini merupakan keterlibatan dalam meningkatkan penyebaran informasi ke seluruh dunia dan memberikan 
konstruksi citra dan wacana kepada dunia melalu media. Kelima, ideoscape (ideologi) yang merupakan idealitas yang bersifat politis yang berhubungan langsung dengan misi global yang diusungnya. Lima unsur yang dijelaskan Appadurai ini, digunakan sebagai konsep dalam menganalisis pola pembentukan identitas keagamaan HTI. Namun dari lima unsur globalisasi ini, HTI lebih dominan menggunakan unsur ideologi dalam menyebarkan paham dan nilai-nilai organisasinya. Ideologi dan doktrinasi merupakan tahap awal dari penyebaran paham khilafah yang menjadi inti dari gerakan HTI. Menurut Ritzer, penggunaan akhiran "scape" dalam istilah Appadurai untuk menyampaikan ide bahwa proses ini cair, tak teratur, dan berbentuk variabel yang konsisten dengan heterogenisasi, bukan homogenisasi (Ritzer, 2014). Teori Appadurai mengarah kepada heterogenisasi dan tidak sesuai dengan cita dasar HTI yang mengarah kepada homogenisasi identitas. Namun, kenyataannya, justru terjadi ambivalensi identitas HTI dengan Hizbut Tahrir gobal secara kultural.

Pembentukan identitas di HTI ditentukan juga oleh lima faktor sebagaimana yang dijelaskan oleh Appadurai tersebut. Pertama, tokoh sentral dalam pemikiran HTI mengacu kepada tokoh pendirinya, Taqiyuddin an-Nabhani. An-Nabhani menjadi aktor penggagas sekaligus sebagai konseptor organisasi. Karyakaryanya dijadikan rujukan utama dan referensi yang harus dijadikan pegangan oleh para pengikutnya. Kedua, penguasaan terhadap teknologi sangat difokuskan agar bisa melakukan ideologisasi transnasional dan transkultural. Ketiga, HTI memiliki usaha-usaha yang memperkuat jaringan ekonominya dan mengharapkan bantuan para anggotanya. Dalam masalah permodalan, sangat sulit sekali dicari referensi mengenai pendanaan organisasi ini. Keempat, HTI menjadikan media sebagai instrumen utama dalam penyebaran gagasan dan doktrinasi organisasinya. Jaringan global HTI terjalin dengan mengoptimalkan perananan media. Kelima, dalam masalah ideologi politik, tujuan besar yang ingin dicapai adalah khilafah yang diklaim sebagai penerapan agama secara holistik. Hal ini bisa disebut sebagai khalifatisasi dalam pelbagai sistem yang dianggap sebagai Islam yang benar (truly moslem). Dilihat dari ideologi global yang diusung oleh HTI, sebenarnya konsep khilafatisasi yang dilakukan oleh HTI hampir sama dengan konsep McDonaldisasi yang dibangun oleh Ritzer. Perbedaannya terletak pada tujuan besarnya, HTI dengan tujuan penyebaran ideologis sedangkan McDonald dengan tujuan kepentingan ekonomis.

\section{Objek Kajian}

\section{a. Sejarah HTI}

Dalam website resminya http://hizbut-tahrir.or.id/, ${ }^{1}$ disebutkan

${ }^{1}$ Website resminya sekarang sudah tidak bisa diakses seiring dengan keluarnya keputusan pembubaran HTI. Pada tanggal 19 $\underline{\text { Juli }} 2017$ pemerintah Indonesia melalui Kem enterian Hukum dan HAM secara resmi mencabut status badan hukum ormas $\underline{\text { Hizbut }}$ 
bahwa Hizbut Tahrir merupakan organisasi politik Islam global yang berdiri pada tahun 1953 di al-Quds (Baitul Maqdis), Palestina dan didirikan oleh Taqiyuddin AnNabhani (1909-1977). Lalu organisasi ini mengalami perkembangan di pelbagai negara dan masuk ke Indonesia pada tahun 1980an dengan merintis lembaga-lembaga dakwah di kampus-kampus besar. Pada tahun 1990-an Hizbut Tahrir merambah ke masyarakat umum melalui pelbagai aktifitas dakwah di mesjid, perkantoran, perumahan, dan perusahaan. Dalam menjalankan organisasinya, HTI merumuskan tiga metode dakwahnya, yaitu: pertama, melakukan pembinaan dan pengkaderan. Hal ini dilakukan untuk membentuk kader-kader HTI yang mengerti dan memahami struktur berpikir dan metodologi HTI. Alasan lain kaderisasi HTI juga didasarkan pada pembentukan kerangka partai. Jika dilihat dari alasan ini, maka bisa dilihat bahwa HTI punya tujuan untuk bertransformasi menjadi partai politik. Kedua, melakukan interaksi dengan umat agar ajaran dan pemikiran HTI bisa tersebar. Ketiga, tahap penerimaan kekuasaan yang

Tahrir Indonesia (HTI) berdasarkan Surat Keputusan Menteri Hukum dan HAM Nomor AHU-30.AH.01.08 tahun 2017 tentang pencabutan Keputusan Menteri Hukum dan HAM nomor AHU0028.60.10.2014 tentang pengesahan pendirian badan hukum perkumpulan HTI. Pencabutan tersebut dilakukan sebagai tindaklanjut Peraturan Pemerintah Pengganti Undang-undang (Perppu) Nomor 2 Tahun 2017 yang mengubah UU Nomor 17 Tahun 2013 tentang Organisasi Kemasyarakatan. ditujukan sebagai penerimaan terhadap Islam secara holistik.

Pemimpin global (amir) Hizbut Tahrir yang pertama yaitu Taqiyuddin An-Nabhani (1909-1977) selama 25 tahun. Setelah itu sejak tahun 1977, Hizbut Tahrir dipimpin oleh Abdul Qadim Zallum (19242003) selama 25 tahun. Selanjutnya, amir Hizbut Tahrir bernama 'Atha bin Khalil bin Ahmad bin Abdul Qadir al-Khathib Abu ar-Rasytah (1943). 'Atha Abu ar-Rasytah dipilih pada tanggal 13 April 2003 (HTI, 2009). Pimpinan Hizbut Tahrir tidak bisa diidentifikasi keberadaannya karena berdasarkan pernyataan di website resmi organisasinya, pimpinan mereka hanya disebutkan berada di salah satu negara muslim. Hal itu dilakukan oleh Hizbut Tahrir dengan alasan melindungi keamanan pimpinan mereka karena seringkali mendapatkan penyiksaan dan bahkan menjadi korban dari pihak yang tidak menyukai cara dakwah Hizbut Tahrir.

$\begin{array}{clr}\text { Dalam } & \text { posisinya } & \text { sebagai } \\ \text { organisasi, } & \text { Hizbut } & \text { Tahrir }\end{array}$ menyebutkan dirinya sebagai partai politik Islam. Penyebutan sebagai partai politik Islam tersebut didasarkan pada perspektif bahwa tidak ada dikotomi antara agama dan politik. Artinya agama tidak bisa dipisahkan dari politik dan begitu juga sebaliknya. Dalam teori hubungan antara agama dan negara, pandangan HTI ini disebut sebagai paradigma integralistik. Paradigma integralistik memandang bahwa agama menyatu dalam soal politik dan negara. Dalam paradigma ini, kepala negara merupakan kepala pemerintahan dan include sebagai seseorang yang memegang otoritas 
agama. Negara merupakan lembaga politik dan agama sekaligus. Karenanya menurut paradigma ini, kepala negara adalah pemegang kekuasaan agama dan kekuasaan politik.

diselenggarakan

Pemerintahan

kedaulatan

Illahi

berdasarkan

sovereignity). Menurut Tibi, gagasan negara Islam muncul karena adanya pemahaman yang berkembang bahwa itu merupakan inti dari Islam. Namun menurutnya, gagasan negara Islam hanyalah sebuah substansi dari politik Islam dan bukan merupakan agama Islam itu sendiri. Karena tidak ditemukan konsep pemerintahan Islam yang digariskan oleh Alquran dan sunnah (Tibi, 2001). Paradigma seperti ini dikenal juga dengan sistem khilafah. Seorang khalifah menjadi pemimpin tertinggi yang perintah dan larangannya harus ditaati.

Paradigma ini menurut Rifa'i mirip dengan sistem teokratis absolut dengan beberapa distingsi. Kemiripannya dalam hal seorang khalifah harus menjadikan kekuasaannya terikat dengan prinsipprinsip Alquran dan sunnah (Rifa'i, 2013). Paradigma integralistik dalam pemahaman seperti itu dianut oleh kelompok Syiah. Hal itu disimpulkan berdasarkan pemahaman Syiah tentang imamah. Namun, menarik untuk dicermati pendapat dari Rifa'i yang membedakan antara konsep imamah dan khilafah. Konsep khilafah terkait dengan manajemen dan pemerintahan, sedangkan konsep imamah terkait dengan pemahaman dan pengetahuan (Rifa'i, 2013; M. Wahid \& Rumadi, 2001). Selain itu, Shihab menjelaskan bahwa dalam suatu negara Islam Syiah, imam berfungsi sebagai pengarah haluan negara walaupun tidak mutlak memegang kekuasaan eksekutif (Shihab, 2007).

Landasan tekstual berdirinya HTI didasarkan pada Alquran surat Ali Imran ayat 104. Sedangkan landasan sosiologis berdirinya HTI bisa disederhanakan menjadi kekecewaan mereka terhadap kondisi masyarakat Islam secara global yang dianggap sudah mengalami dekadensi moral dan nilai-nilai keagamaan yang semakin ditinggalkan. Dalam ungkapan lain bisa disebutkan bahwa berdirinya HTI merupakan bentuk lain dari revivalisme Islam. Revivalisme Islam HTI ini didasarkan pada dua hal, yaitu: melawan sistem, aturan, dan perundangan-undangan negara kufur serta melawan hegemoni negaranegara kufur. Sedangkan tujuan berdirinya HTI secara jelas disebutkan untuk mendirikan Daulah Khilafah Islamiyah.

Tujuan yang ingin dicapai oleh HTI terjebak pada romantisme sejarah masa lalu dengan dalih pendirian negara madinah oleh Nabi. Mereka mengacu juga kepada puncak peradaban Islam yang dicapai oleh khilafah-khilafah setelahnya. Kebangkitan barat pada abad pencerahan beriringan dengan mundurnya peradaban Islam di semua wilayah. Hal inilah yang menjadi pemicu HTI untuk berusaha membangkitkan kejayaan masa lalu tersebut. Gerakan ini bisa disebut sebagai revivalisme Islam yang sering dideskripsikan secara sederhana sebagai reaksi dan respon terhadap imperialisme Barat. Namun sisi lain yang harus dilihat adalah, 
kemunduran Islam sudah dimulai sebelum modernisasi. Dalam kesimpulan Esposito, revivalisme pada abad ke-18 dan abad ke-19 sebelum gerakan modernisasi itu telah menumbangkan bagan politik Islam dan memberikan legacy (warisan) kepada gerakan Islam pada abad ke-20. Motivasi gerakan revivalisme tersebut menurut Esposito merupakan jawaban dari kelemahan intern muslim sendiri (Esposito, 1990).

\section{b. HTI dan Tujuannya di Indonesia}

HTI mengeluarkan manifesto ajarannya untuk Indonesia dalam pelbagai hal dan permasalahan. Manifesto tersebut merupakan pernyataan terbuka tentang tujuan dan pandangan HTI terhadap kondisi negara Indonesia. Pernyataan terbuka HTI tersebut dipublikasikan dalam buku "Manifesto Hizbut Tahrir untuk Indonesia" yang diterbitkan oleh HTI. Di dalam buku ini, sangat jelas tujuan utama keberadaan HTI di Indonesia merupakan usaha untuk mendirikan negara khilafah. Agenda besar tersebut dibahasakan sebagai usaha penyatuan kembali negara Islam (reunifikasi).

Dalam pandangan yang sangat sederhana, HTI menyimpulkan bahwa semua dekadensi dan involusi yang terjadi di negara-negara Islam termasuk di Indonesia disebabkan oleh tidak adanya penerapan sistem Islam (HTI, 2009). Buku ini dengan eksplisit menyatakan keinginan untuk menjadikan salah satu negara-negara muslim menjadi negara khilafah dan hal tersebut akan menjadi pemicu berdirinya reunifikasi negara muslim
(HTI, 2009). Pernyataan eksplisit HTI ini merupakan tujuan besar HTI di Indonesia. Artinya, HTI menginginkan Indonesia menjadi negara Islam dan dipimpin oleh seorang khilafah. Dilihat dari tujuan HTI ini bisa disimpulkan bahwa HTI dan ajarannya di Indonesia merupakan gerakan yang akan membahayakan bagi persatuan dan kesatuan Indonesia.

\section{Analisis Pembentukan Identitas HTI}

Antara globalisasi dan pembentukan identitas keagamaan terdapat resiprokalitas (hubungan timbal balik). Pembentukan identitas keagamaan salah satunya disebabkan oleh adanya proses globalisasi. Semakin keras proses globalisasi itu terjadi, maka semakin kuat juga pembentukan identitas keagamaan atau kelompok tertentu ditonjolkan. Proses globalisasi mengarah kepada homogenitas kebudayaan, kesukuan, fashion, etika, dan norma sosial. Di sisi lain, kondisi dunia global terdiri dari pelbagai unsur yang berbeda atau beraneka ragam. Globalisasi dianggap sebagai alat pengaburan ragam kebudayaan dan norma sosial yang ada. Maka wajar jika globalisasi akan menciptakan pertarungan identitas, khususnya dalam bidang keagamaan. Hal ini bisa dilihat dari fashion sebagai salah satu cara menegaskan identitas. Sekelompok muslim menganggap bahwa berjubah, berjenggot, dan celana cingkrang merupakan identitas keagamaan dan antitesis dari fashion non Islam.

Menurut Rutherford, identitas merupakan satu mata rantai masa lalu dengan hubungan sosial, kultural, dan 
ekonomi di dalam ruang dan waktu satu masyarakat hidup. Setiap invidu merupakan sintesis dari masa lalu dan masa sekarang dan segala hubunganhubungannya (Rutherford, 1990). Jika digunakan pendekatan definitif sesuai dengan pendapat Rutherford, maka bisa disimpulkan bahwa identitas hari ini merupakan bentukan sosio kultural dan politik masa lalu yang bermetamorfosis menjadi identitas sekarang. Namun definisi yang diberikan Rutherford seolaholah mengabaikan adanya sebabsebab terjadinya pengaburan identitas karena faktor lain. Namun kita juga tidak bisa menafikan apa yang telah disimpulkannya tentang identitas. Masih banyak definisi lain yang diberikan oleh para Ahli tentang identitas, namun tulisan ini hanya beranjak dari tesis yang diajukan oleh Rutherford. Tesis yang dibangunnya menandakan adanya korelasi antara masa lalu dan masa sekarang dalam pembentukan identitas.

Merujuk kepada analisis yang diberikan oleh Meuleman, bahwa globalisasi merupakan proses menuju ke arah saling ketergantungan pelbagai entitas yang ada. Fenomena yang terjadi di wilayah tertentu bisa jadi akan berpengaruh terhadap wilayah lainnya. Bahkan Meuleman mengembangkan tiga posisi dalam melihat Islam ketika berhadapan dengan globalisasi. Posisi tersebut akan membawa implikasi yang berbeda, yaitu sebagai aktor, reaktor, atau sebagai korban (actor, re-actor, or as victim) ketika berhadapan dengan proses globalisasi (Meuleman, 2005).

Malik menjelaskan bahwa para ulama tradisional dan juga lembaga-lembaga keagamaan sangat penting peranannya dalam menjawab tantangan globalisasi dan modernisasi. Proses globalisasi dan modernisasi bisa dinterpretasi secara spesifik sesuai dengan kebutuhan lokal dan situasi tertentu (Malik, 2005). Proses globalisasi dalam membentuk identitas bukanlah merupakan hal yang baru dalam dunia Islam. Sebagai contoh untuk perbandingan, bisa dilihat dari karakteristik identitas Islam yang ada di Indonesia. Islam di Indonesia merupakan sintesis Islam universal yang sudah berasimilasi dengan kultur lokal. Azra menjelaskan bahwa globalisasi bukanlah sesuatu yang baru dalam Islam. Hal ini didasarkan pada fakta historis yang menggambarkan bahwa di Indonesia proses globalisasi itu terjadi secara terus-menerus. Globalisasi yang dimaksudkan oleh Azra tersebut merupakan globalisasi dalam tataran wacana agama dan intelektual Islam di Indonesia langsung bersumber dan berdialektika dengan ulama Mekah dan Madinah (Azra, 2005). Proses globalisasi yang terjadi terus-menerus inilah yang mengkontruksi identitas Islam di Indonesia. Namun dalam perspektif Thomas, globalisasi menyebabkan pelemahan identitas individu dan identitas kolektif (nasionalisme, etnis, dan agama) (Thomas, 2007).

Dilihat dari perspektif identitas, HTI merupakan organisasi transnasional yang beridentitas ganda. Disatu sisi, HTI harus mengacu kepada organisasi induknya, namun disisi lain harus mampu bersifat adapatif terhadap karakteristik Islam di Indonesia. 
Adaptasi kultural tersebut mutlak harus dilakukan oleh HTI agar bisa diterima ajaran-ajarannya oleh masyarakat Indonesia. Gerakan HTI di Indonesia tidak bisa dikategorisasikan sebagai gerakan politik praktis. Padahal pada awalnya Hizbut Tahrir didirikan sebagai gerakan dan organisasi politik. Namun tipologi gerakan HTI cenderung lebih soft dan tidak melibatkan diri di politik praktis dan tidak melakukan gerakan radikal. Bagi HTI, uslub politik yang digunakan untuk mewujudkan khithah politik dapat berubah-ubah sesuai dengan tuntutan kepentingan (Taqiyyudin An-Nabhani, 2005).

Sebagaimana yang dijelaskan oleh Qomar, era reformasi membawa perkembangan signifikan terhadap kelompok-kelompok Islam radikal di Indonesia dan HTI termasuk kelompok radikal yang bercorak transnasional (Qomar, 2012). Hal itu dimaknai sebagai konsekuensi logis dari era reformasi. Pendapat Qomar sangat rancu jika dilihat dari fakta dan peristiwa radikalisme di Indonesia. Hampir dari setiap tindakan radikal atau terorisme yang terjadi di Indonesia, tidak pernah melibatkan HTI sebagai sebuah organisasi. Radikal yang dimaksudkan oleh Qomar lebih tepatnya disebut sebagai radikal dalam konteks pemikiran. Penyebutan kata radikal Islam dan fundamentalis Islam tersebut juga ditolak oleh HTI. Bagi mereka sebutan tersebut mengandung makna pejoratif dan mengkerdilkan Islam. Bagi HTI, ideologi dan identitas Islam yang ditonjolkan merupakan identitas Islam yang sebenarnya (truly moslem). Klaim kebenaran tersebutlah yang menjadikan HTI dikategorikan dalam konsep radikal dalam pemikiran.

Identitas keagamaan yang ditampilkan HTI merupakan bentuk dari hibridasi kultural dan identitas hibrida. Identitas tersebut terbentuk dikarenakan adanya persilangan kultural antara klaim kebenaran identitasnya dengan identitas masyarakat Indonesia yang plural. Maka bisa dipahami bahwa HTI mempunyai corak dan ragam gerakan yang berbeda dengan organisasi induknya. Walaupun secara pemikiran dan ideologi selalu terhubung dan tidak bisa lepas dari organisasi induknya, identitas dan kultural anggota HTI sangat dipengaruhi oleh kultur inti masyarakat Indonesia. Dalam konteks sederhana inilah terlihat ambiguisitas dan ambivalensi identitas HTI. HTI dan organisasi induknya tidak bisa menerapkan karakter dan identitas yang sama di tempat dan kondisi kultural yang berbeda. Homogenisasi yang terjadi di HTI hanyalah dalam konteks penyebaran paham khilafah. Sedangkan dalam gerakan dan identitas lokalitasnya bersifat heterogen.

Misi dan ajaran agama yang dibawa dan digunakan oleh HTI tidak bisa dilepaskan sebagai faktor penentu pembentukan identitas keagamaan HTI. Respon agama dan interpretasi agama terhadap globalisasi juga akan menghasilkan pembentukan identitas. Menurut Yasraf, di dalam kebudayaan terdapat persoalan tentang pembentukan konsep diri (self), yaitu persepsi seorang individu terhadap dirinya 
yang disebut sebagai problem subjektifitas. Subjektifitas memberikan seorang individu tidak saja tentang konsep dirinya, tetapi sekaligus memberi sebuah posisi di dalam relasi intersubjektifitasnya (Piliang, 2011). Persoalan subjektifitas adalah persoalan identitas, yaitu bagaimana seorang individu atau kelompok memosisikan dirinya diantara individu atau kelompok lain. Menurut Miguel deBeistequi sebagaimana yang dikutip oleh Yasraf, identitas dibangun berdasarkan dua konsep yang saling menguatkan yaitu konsep persamaan (sameness) dan konsep perbedaan (difference). Dua konsep inilah yang berpengaruh terhadap pembentukan bahkan perubahan identitas beragama dalam merespon globalisasi.

\section{Terdapat}

beberapa

karakteristik globalisasi HTI, yaitu: Pertama, anggotanya cenderung memiliki kepentingan global yang sama (ide khilafah). Kedua, berusaha meningkatkan peranan kontrol terhadap negara dengan melakukan gerakan-gerakan yang berbentuk kontrol sosial keagamaan (demontrasi) dan bersifat kritis terhadap kebijakan di luar nilai-nilai yang dianutnya. Ketiga, cenderung melakukan simplifikasi terhadap pelbagai permasalahan dan menjadikan ajaran dan nilai yang dianutnya sebagai solusi. Sebagai salah satu contoh, kondisi masih banyaknya warga negara yang berada di bawah garis kemiskinan dianggap karena negara tidak menerapkan ekonomi Islam. Kegagalan negara terjadi karena dianggap bertentangan dengan ajaran Islam. Keempat, perbedaan kewarganegaraan tidak menghalangi untuk menjalankan misi khilafah dan penyeragaman misi tersebut dijadikan agenda besar yang harus diwujudkan.

Peranan ideologi dan persebaran ideologi HTI sebagai misi global membuktikan bahwa proses globalisasi dalam tubuh HTI sangat kuat. Proses keberlangsungan globalisasi ini membenturkan budaya baru dengan budaya lokal dan pada akhirnya juga memunculkan penegasan identitas lokalitas. Hal ini tidak bisa dilepaskan dari konteks global keberlangsungan globalisasi secara umum. Menurut Esposito, penegasan identitas komunal merupakan representasi dari tuntutan terhadap pemberdayaan rakyat dan pengakuan identitas dalam konteks pengalaman manusia yang semakin global (Esposito \& Voll, 1999). Dapat dipahami bahwa pembentukan identitas tersebut merupakan hasil dari benturan antar kultural dan identitas yang sifatnya majemuk dan plural. Maka tidak mungkin untuk memberlakukan identitas tunggal atau homogenisasi kultural. Dilihat dari lima scape yang diuraikan oleh Appadurai, maka proses pembentukan identitas HTI tidak lepas dari konsep tersebut.

Pertama, an-Nabhani merupakan tokoh sekaligus peletak dasar pembentukan identitas HTI. Karya-karya an-Nabhani merupakan rujukan utama dan sekaligus menjadi pedoman strategi serta taktik gerakan bagi organisasi. Menurut Jamhari dan Jajang Nahroni, pada dasarnya pemikiran dan gagasan yang diproklamirkan oleh an-Nabhani mempunyai beberapa persamaan 
dengan pemikiran Muhammad Rasyid Ridha, dan bahkan hampir sama dengan Ibnu Taimiyah dan Ahmad bin Hanbal (Jamhari \& Jahroni, 2004). An-Nabhani pernah berguru dengan beberapa ulama yang merupakan murid langsung dari Ridha dan mengembangkan pemikiran dari guru-gurunya tersebut. keberadaan an-Nabhani dan pelbagai aspek pemikirannya merupakan ruh gerakan bagi seluruh anggota HTI sehingga membentuk karakter dan identitas ideologi dan keberagamaannya. Karya-karya anNabhani terdiri dari dua hal, yaitu kitab-kitab yang berupa tanzhiriyah (penetapan pemahaman/pandangan) dan juga berupa tanzhimiyah (penetapan peraturan). Pemikiran anNabhani didominasi oleh visi besar penegakan daulah Islamiyah. Posisi an-Nabhani tidak hanya sebagai peletak dasar pendirian organisasi, tapi juga sebagai landasan ideologis dan politis bagi HTI.

Kedua, penguasaan terhadap teknologi dan media merupakan instrumen untuk penyebaran misi ideologis. Hizbut Tahrir di pelbagai negara pasti mempunyai website organisasi yang sebagian besar isinya sama antara satu dengan yang lainnya. Hal yang membedakan antar satu dengan yang lainnya hanya berada pada penambahan pada isu-isu lokalitas yang dikaitkan analisisnya dengan cara pandang HTI. Namun misi globalnya tetap sama. Hal ini membuktikan bahwa homogenisasi identitas di organisasi ini masih sangat sulit tercapai karena adanya perhatian yang berbeda terhadap isuisu lokalitas masing-masing negara. Website induknya http://www.hizb- ut-tahrir.org/ yang menjadi patokan isu, wacana, dan analisis kondisi global bagi seluruh anggotanya di negara manapun. HTI tidak memiliki amir di Indonesia. Dalam konsep organisasi dan cara pandang komunikasinya, di pelbagai perwakilannya hanya menempatkan juru bicara. Di Indonesia juru bicaranya adalah Ismail Yusanto. Juru bicara di HTI akan melakukan penyebaran press release mengenai sikap organisasi dalam merespon isuisu besar yang terjadi. Penyampaian press release organisasi akan selalu dipublikasikan di website organisasi. Jadi jelaslah bahwa penguasaan terhadap teknologi dan media merupakan sarana untuk membentuk identitas keberagamaan HTI.

Ketiga, sumber pendanaan HTI merupakan poin penting penegasan identitas. Menurut keterangan Syarif Zayad (juru bicara Hizbut Tahrir Mesir), sumber pendanaan organisasi didapatkan dari sumbangan para shabab (aktivis) Hizbut Tahrir saja. Dalam penjelasannya Zayad menyatakan bahwa Hizbut Tahrir menolak untuk mengambil segala dana apapun dari negara, lembaga, ataupun individu yang bukan anggotanya. Jika keterangan dari Zayad dibenarkan, maka bisa dibangun asumsi bahwa aktivis dan anggotanya sudah sangat banyak sehingga mampu memberikan pendanaan terhadap organisasi. Sampai saat ini, keterangan mengenai sumber pendanaan Hizbut Tahrir sangat tertutup dan tidak bisa diakses. Namun yang jelas, dilihat dari militansi dan doktrinasi yang ditanamkan kepada anggotanya, sumbangan terhadap organisasi bisa 
saja menjadi dana awal untuk pendanaan. Belum lagi kegiatankegiatan sosial yang mereka lakukan dan aktivitas dakwah yang dilakukan oleh HTI di Indonesia sangat jarang dalam bentuk fund raising. Pemikiran HTI dari sisi ekonomi juga sangat menarik dengan menekankan kepada tawaran sistem ekonomi yang dianggap bersumber dari ajaran Islam. HTI menyerukan kepada masyarakat muslim untuk kembali menggunakan emas (dinar) dan perak (dirham) sebagai alat tukar. Hal ini disebabkan oleh dominasi dolar Amerika yang menghegemoni seluruh perekonomian negara-negara di dunia (Jamhari \& Jahroni, 2004).

Keempat, ideologi khilafah sebagai pengikat identitas global Hizbut Tahrir. Menurut Jamhari dan Jajang Jahroni, konsep khilafah yang dibangun oleh Hizbut Tahrir berbeda dengan gerakan Pan Islamisme yang dibangun oleh Jamaludin al-Afghani (Jamhari \& Jahroni, 2004). Pan Islamisme menekankan kepada kerja sama antar negara Islam yang independen untuk mencapai tujuan bersama, tujuan ini bisa tujuan politik, ekonomi, sosial, dan keagamaan. adapun khilafah merupakan ide tentang unifikasi dunia Islam. Seluruh dunia Islam berada di bawah satu pimpinan yang dinamakan khalifah. Khalifah memiliki kekuasaan untuk mengatur segala hal mengenai pemerintahan dan kehidupan sosial kemasyarakatan. Sistem kekhalifahan Islam yang dimaksudkan merujuk kepada sistem khalifah pada masa awal Islam. Dalam penjelasan anNabhani mengenai pendirian daulah Islamiyah disebutkan bahwa pendirian terhadap daulah Islamiyah merupakan kewajiban yang harus dilakukan untuk penegakan syariat Islam (Taqiyuddin An-Nabhani, 2012). Bagi an-Nabhani, tanpa syariat Islam hanya ada kesenangan dan kesejahteraan utopis dan sistem pemerintahan Islam akan menegaskan hakikat kemaslahatan. Ideologi khilafahisme inilah yang menjadi pokok dan identitas inti dari HTI. Walaupun manifestasi dan gerakannya berbeda variannya antara satu negara dengan negara lain, namun misi khilafah dan daulah Islam tetap menjadi tujuan prioritas.

Dari segi pembentukan identitas, keempat ideologi di atas merupakan faktor dominan dalam pembentukan identitas HTI. Namun hal terpenting dan paling berpengaruh dalam menentukan identitas kultural, gagasan, dann politik HTI bertumpu pada ide dan gagasan pendirian daulah Islam. Hal ini merupakan tujuan utama yang menjadi pertimbangan reflektif bagi HTI dalam menentukan sikap, aksi, dan manifesto politiknya. Dalam konsep khilafah, terjadi konvergensi kultural dalam gerakan Hizbut Tahrir. Antara satu negara dengan negara lainnya terdapat persamaan dalam perjuangan utama mendirikan negara Islam. Namun ide khilafah ini dalam sisi yang berbeda juga melahirkan diferensialisme kultural. Artinya, ide khilafah tidak akan pernah tergerus oleh arus globalisasi yang datang dari luar Hizbut Tahrir. Ide khilafah dan daulah Islam itu sendiri merupakan misi global yang harus diperjuangkan. Sebagaimana analisis Pieterse, diferensialisme kultural ini bisa menyebabkan HTI menjadi 
sangat tertutup dalam masalah ideologi.Karena ideologi merupakan hal yang sangat urgen bagi Hizbut Tahrir, maka wajar terjadi benturan dengan ideologi lain. Dalam pandangan yang sangat ekstrim, Ariel Cohen menyamakan antara Hizbut Tahrir dengan komunisme. Hal itu dilihat dari ketertutupan ideologi yang dianut dan diyakini kebenarannya (Cohen, n.d.). Ideologi tertutup ini yang ditakutkan akan berujung kepada benturan peradaban sebagaiman tesis yang dibangun oleh Huntington.

Dalam paradigma ketiga dalam pandangan Pieterse mengenai hibdiridasi kultural, sebenarnya kultur dan identitas luar HTI bersifat hibrida. Walaupun identitas inti dari sisi ideologi tidak berubah dan bersifat tertutup, namun identitas yang lain mengalami perubahan. Hal itu bisa dilihat dari pemanfaatan media dalam menyebarkan misi globalnya. Pemanfaatan teknologi dan media merupakan imbas dari proses keberlangsungan ideologi yang terjadi di HTI. Sebagaimana yang dijelaskan sebelumnya, hibridasi kultural menekankan perpaduan kultur sebagai akibat dari globalisasi dan munculnya kultur hibrida, dari integrasi global dan lokal yang tidak dapat direduksi dari kultur global ataupun dari kultur lokal. Hal ini juga bisa dilihat dari penerapan gaya dan strategi dakwah HTI. Pada dasarnya HTI merupakan organisasi politik, namun di Indonesia HTI tidak bertransformasi menjadi partai politik.

\section{KESIMPULAN}

Proses $\begin{array}{r}\text { keberlangsungan } \\ \text { globalisasi dan }\end{array}$ pembentukan
identitas keberagamaan memiliki
hubungan timbal balik serta saling
mempengaruhi.
membawa perubahan $\begin{array}{r}\text { Globalisasi } \\ \text { identitas }\end{array}$
kultural dan juga dengan sendirinya
menguatkan identitas. Penguatan
identitas tersebut merupak counter
terhadap globalisasi yang dimaknai
sebagai westernisasi. Namun
pemaknaan globalisasi sebagai
westernisasi merupakan pemahaman
simplifikasi yang perlu diuji dan
tidak bisa digeneralisir

kesimpulannya. Memang terdapat beberapa efek negatif globalisasi, namun proses keberlangsungan globalisasi merupakan peluang besar untuk dakwah Islam. Kondisi dan proses globalisasi bisa dijadikan media untuk pengembangan dakwah Islam rahmatan lil 'alamin.

Globalisasi merupakan konsep yang tidak bisa dihindarkan oleh siapapun termasuk HTI. HTI itu sendiri juga membawa tipologi globalisasi dan mempunyai misi global yang disebarkan kepada seluruh dunia. Hal tersebut merupakan pengejawantahan konsep khilafah yang akan mendirikan daulah Islam. Dalam pembentukan identitas organisasi dan penyeragaman identitas tersebut, terdapat tiga faktor penentu, yaitu: pengaruh dan pemikiran serta gagasan-gagasan an-Nabhani, penguasaan terhadap teknologi dan media, penguatan basis finansial organisasi, serta ideologisasi dalam bentuk daulah Islam yang dinamakan dengan khilafah. Ideologi khilafah ini menjadi faktor dominan penyeragaman identitas HTI dan 
mengikat seluruh aktivis dan anggotanya.

Hal lain yang juga patut dicermati adalah, ambiguisitas dan ambivalensi HTI dalam menghadapi globalisasi. Disatu sisi HTI menjadikan kondisi globalisasi sebagai peluang penyebaran ideologi khilafah, namun disisi lain menolak globalisasi. Kegagapan tersebut juga

\section{Daftar Kepustakaan}

Al-Rodhan, Nrf and G. Stoudmann. 2006. "Definitions of Globalization: A Comprehensive Overview and a Proposed Definition." Occasional Papers, Geneva Centre ....

Appadurai, Arjun. 1996. Modernity at Large: Cultural Dimension of Globalization. London: University of Minnesota Press.

Azra, Azyumardi. 2005. "Globalization of Indonesian Muslim Discourse: Contemporary ReligioIntellectual Connections Between Indonesia and the Middle East." in Islam in the Era of Globalization: Muslim Attitudes Toward Modernity and Identity, edited by J. Meuleman. London \& New York: RoutledgeCurzon.

Cohen, Ariel. n.d. "Hizb Ut-Tahrir: An Emerging Threat to U.S. Interests in Central Asia| The berlangsung ketika HTI berasimilasi dengan budaya lokal. Khususnya konsep budaya nusantara. Keberlangsungan organisasi ini di Indonesia mendapat tantangan serius dari keberagaman budaya yang ada. Artinya, misi penyeragaman ideologi khilafah tidak akan bisa diraih jika HTI masih bersifat tertutup dan mengabaikan pluralitas kultural di Indonesia.

Heritage Foundation." Retrieved June 6, 2020 (https://www.heritage.org/eur ope/report/hizb-ut-tahriremerging-threat-us-interestscentral-asia).

Esposito, John L. 1990. Islam Dan Politik. Jakarta: Bulan Bintang.

Esposito, John L. and John O. Voll. 1999. Demokrasi Di NegaraNegara Muslim: Problem Dan Prospek. Bandung: Mizan.

Giddens, Anthony. 1998. The Third Way: The Renewal of Democracy. Cambridge: Polity Press.

Hopkins, Dwight N. 2001. Religion/Globalization.

London: Duke University Press.

HTI. 2009. Manifesto Hizbut Tahrir Untuk Indonesia: Indonesia, Khilafah Dan Penyatuan Kembali Dunia Islam. Jakarta: HTI.

Jamhari and Jajang Jahroni. 2004. Gerakan Salafi Radikal Di 
Indonesia. Jakarta: Rajawali Pers.

Kumar. 2003. "A Critical Methodology of Globalization: Politics of the 21st Century?" Indiana Journal of Global Legal Studies.

Malik, Jamal. 2005. "The Mull" and the State: Dynamics of Islamic Religious Scholars and Their Institutions in Contemporary Pakistan1." Pp. 163-68 in Islam in the Era of Globalization: Muslim Attitudes towards Modernity and Identity, edited by $\mathrm{J}$. Meuleman. London \& New York: RoutledgeCurzon.

McLuhan, Marshall. 1962. The Guttenberg Galaxy. Kanada: University of Toronto Press.

Meuleman, Johan, ed. 2005. Islam in the Era of Globalization: Muslim Attitudes Toward Modernity and Identity. London \& New York: RoutledgeCurzon.

An-Nabhani, Taqiyuddin. 2012. Daulah Islam. Jakarta: HTI Press.

Taqiyyudin. 2005. Konsepsi Politik Hizbut Tahrir. Jakarta: HTI Press.

Ohmae, Kenichi. 1992. The Borderless World: Power and Strategy in the Global Marketplace. London: HarperCollins.
Pasha, Mustapha Kamal. 2002. "Predatory Globalization and Democracy in the Islamic World." Annals of the American Academy of Political and Social Science.

Pieterse, Jan Nederveen. 1996. "Globalisation and Culture: Three Paradigms." Economic and Political Weekly.

Pieterse, Jan Nederveen. 2004. Globalization and Culture: Global Melange. Lanham: Rowman and Littlefield.

Piliang, Yasraf Amir. 2011. BayangBayang Tuhan Agama Dan Imajinasi. Bandung: Mizan.

Qomar, Mujammil. 2012. Fajar Baru Islam Indonesia: Kajian Komprehensif Atas Sejarah Dan Dinamika Intelektual Islam Nusantara. Bandung: Mizan.

Rifa'i, Musthofa. 2013. Islam Kita: Titik Temu Sunni-Syiah. Jakarta: Fitrah.

Ritzer, George. 2014. Teori Sosiologi Modern. Jakarta: Kencana Prenadamedia Group.

Ritzer, George and Paul Dean. 2013. Globalisasi: The WileyBlackwell Companion to Sosiologi. edited by G. Ritzer. Yogyakarta: Pustaka Pelajar.

Rosenberg, Justin. 2000. Follies of Globalization Theory: Polemical Essays. London: Verso.

Rutherford, Jonathan. 1990. Identity: Community, Culture, 
Difference. London: Wahid, Abdurrahman, ed. 2009. Ilusi

Lawrence \& Wishart.

Shihab, M. Quraish. 2007. SunnahSyiah, Bergandengan Tangan! Mungkinkah?: Kajian Atas Konsep Ajaran Dan Pemikiran. Jakarta: Lentera Hati.

Subhan, Zaitunah. 2005. Pornografi Dan Premanisme. Jakarta: elKahfi.

Thomas, George M. 2007. "The Cultural and Religious Character of World Society." in Religion, Globalization and Culture, edited by P. Beyer and L. Beaman. Leiden: Brill.

Tibi, Bassam. 2001. Islam between Culture and Politics. New York: Palgrave.
Negara Islam: Ekspansi

Gerakan Islam Transnasional Di Indonesia. Jakarta: The Wahid Institute.

Wahid, Marzuki and Rumadi. 2001. Fiqh Madzhab Negara: Kritik Atas Politik Hukum Islam Di Indonesia. Yogyakarta: LKiS.

Weller, Robert P., ed. 2005. Civil Society, Globalization and Political Change in Asia. London.

Wunderlich, Jens Uwe and Meera Warrier. 2007. A Dictionary of Globalization. London \& New York: Routledge. 